\title{
Impact of Seismic Zone on Behavior of Reinforced Concrete Building Structures by Static Non-linear Pushover Analysis
}

\author{
Pankaj R. Shinde ${ }^{1}$, Rajshekhar S. Talikoti ${ }^{2}$ \\ M.Tech. Student, Department of Civil Engineering, SOET, Sandip University, Nashik, India ${ }^{l}$ \\ Professor, Department of Civil Engineering, SOET, Sandip University, Nashik, India ${ }^{2}$ \\ Email: prshinde2210@gmail.com ${ }^{1}$, rajshekhar.talikoti@sandipuniversity.edu.in ${ }^{2}$
}

\begin{abstract}
Building structures ought to be safe for lateral loadings, for the most part because of earthquake. There are four seismic zones- zone 2, 3, 4, and 5 are mainly considered for structural design. There is diverse necessity of the structures in separate zones. So it is especially basic to survey the lead of the structures in various conditions and checking its weakness. Huge amount of development in world is done with Reinforced Concrete (RC) because of accessibility of materials. In this research work, parking+10 storied reinforced concrete 3D residential building models are thought about in zone 3, 4, and 5, i.e. lower to extreme level of seismic conditions. The performance of the RC buildings is surveyed by a static non-linear pushover analysis with ETABS. As shear walls are effective in resisting the lateral forces, the correlation of the buildings without and with shear walls is finished demonstrating the upsides of retrofitting of structure.
\end{abstract}

Keywords- ETABS, pushover analysis, RC building, seismic zones.

\section{INTRODUCTION}

Under long seismic occasions, a structure might be exposed to forces beyond its elastic limit. Sometimes design codes fail to predict the performance level of structures in powerful seismic occasions [10]. Seismic demands can be anticipated by different strategies, yet the standard pushover procedure with lateral force distribution is simple path when contrasted with others [2]. Nonlinear static pushover analysis can distinguish each part of the structure and its deformation demands with exactness when contrasted with dynamic analysis and conventional analysis procedures [7], [9], [13].

In pushover analysis magnitude of lateral loadings on structure is increased gradually in certain predefined design, either certain force value or displacement value (i.e. target displacement) as far as story shear and fundamental mode. In this process, the non-linear behavior of structural elements is inspected [6].

In this study, linear seismic analysis is done first for both the buildings, without and with shear walls under zones 3, 4, and 5 to find out their target displacement. Then the nonlinear static pushover analysis is done considering displacement values of both the buildings to definite respective graphs of force verses displacement relationship. The analysis is done in software, ETABS [3], [12]. The plastic hinges are provided to beam and column elements in the models are according to standard procedure described in FEMA 273 [4], FEMA 356 [5], and ACT-40 [1], documents for $3 \mathrm{D}$ buildings.

\section{LINEAR SEISMIC ANALYSIS}

The linear seismic analysis of building structures is done according to 1893 (Part 1):2002 [14] by either seismic coefficient method or direct combination method of response spectrum. In this, the results are always elastic forces as per limit state i.e. moment, shear and axial forces. Target displacement can be taken out at the end of the analysis for pushover analysis purpose.

Design base shear can be calculated by $V_{b}=A_{h}$.W. Where, W, seismic weight of building and $A_{h}$, horizontal seismic coefficient, calculated by, $A_{h}=$ $\mathrm{ZISa} / 2 \mathrm{Rg}$. Zone factor $(\mathrm{Z})$ is taken according to seismic zones. Importance factor (I) is considered by the occupancy accommodation occupied category of building. Response reduction factor $(\mathrm{R})$ is taken out depending on the type of lateral load resist system used and average response acceleration coefficient $(\mathrm{Sa} / \mathrm{g})$ depends on the type of soil or rock, natural time period and damping of structure, which is given by 2.5 in horizontal portion and in downward sloped portion by $1 / \mathrm{T}, 1.36 / \mathrm{T}$ and $1.67 \mathrm{~T}$, shown in fig. 1 . Acceleration time period $(\mathrm{Ta})$ for infill panels is $0.09 \mathrm{~h} / \mathrm{d}^{-2}$. In this, $\mathrm{h}$ is height of building structure in meters and $d$ is dimension of building structure in basement in meters [14], [15]. 


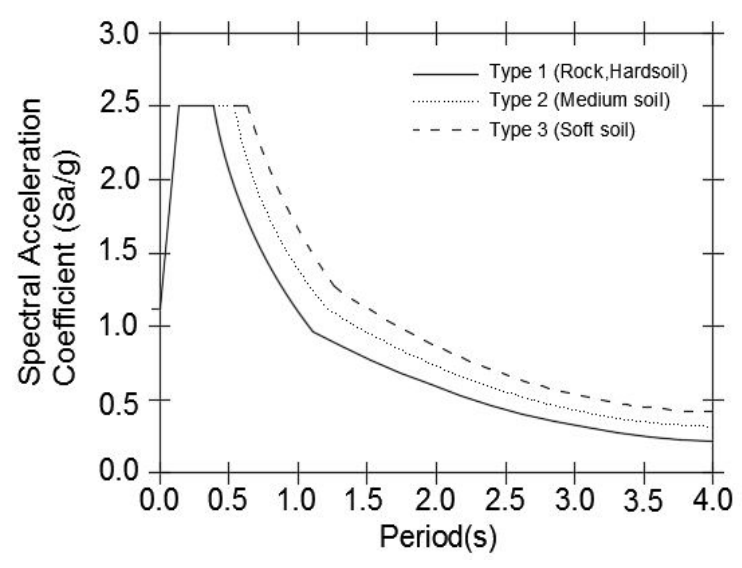

Fig. 1. Average Response Acceleration Coefficient $(\mathrm{Sa} / \mathrm{g})$

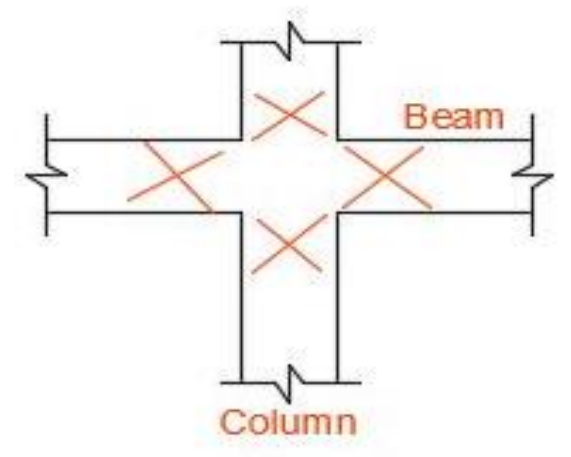

\section{NON-LINEAR STATIC PUSHOVER ANALYSIS}

After lateral forces action, it is thought to be the development of cracks (fig. 2) at specific area in the individuals from model in software while pushover analysis, called as non-linear hinges and taken generally at edges (or at $5 \%$ of member length) and it actually represents localized force displacement relation. Hinges are having of various types that are, flexural hinges, shear hinges and axial hinges. Flexural hinges and shear hinges are embedded into the ends of beams and columns as shown in fig. 2 .

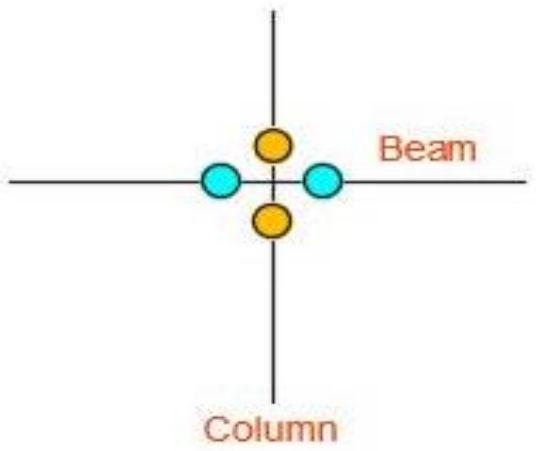

Fig. 2. Cracks and Non-Linear Hinges Location in Members

In pushover analysis procedure, both gravity load cases and lateral load cases [8] are considered, in which gravity loads are applied in the combination $\left\{\right.$ Dead Load +0.25 Live $\left.\operatorname{Load}_{(\leq 3 \mathrm{kN} / \mathrm{m}}{ }^{2}\right)+0.5$ Live $\left.\operatorname{Load}_{\left(>3 \mathrm{kN} / \mathrm{m}^{2}\right)}\right\}$. Structural model is pushed by
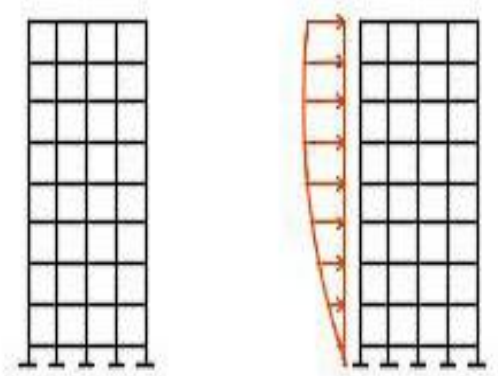

continuously increasing lateral loads up to the target displacement, noted down in the linear seismic analysis. Finally, the relation between load and displacement is calculated [4], [5].

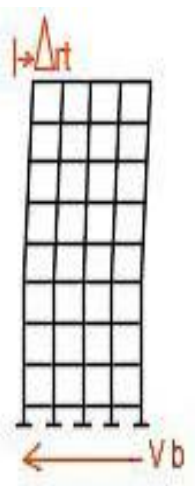

Fig. 3. Pushover Method

The internal forces at every story in the building structures is to be find out by $\mathrm{F}_{\mathrm{i}}=\left(\mathrm{m}_{\mathrm{i}} \mathrm{h}_{\mathrm{i}} \mathrm{k}\right) /\left(\sum \mathrm{m}_{\mathrm{i}} \mathrm{h}_{\mathrm{i}} \mathrm{k}\right)$, which describes the lateral load pattern given in FEMA-273. Where, hi is height of the i-th story above the base and $\mathrm{k}$ is a factor considered for the highest mode effects $(\mathrm{k}=1$ for $\leq 0.5 \mathrm{sec}$ and $\mathrm{k}=2$ for $>2.5 \mathrm{sec}$ and changes in linear mode) [4], [5]. 


\section{Available online at www.ijrat.org}

\section{BUILDING DETAILS}

The two similar reinforced concrete buildings ( $\mathrm{P}+10+$ Head Room), one is without shear walls and other is with shear walls are considered. The building is having a gross area of $494 \mathrm{~m}^{2}$ in total, 4 flats on each floor from 1 to 10. A staircase and lift are provided in the building. Height of the building structure is $38.5 \mathrm{~m}$.
Parking floor height is $2.5 \mathrm{~m}$; each floor is of $3 \mathrm{~m}$ height up to the headroom. The slab thickness is $0.15 \mathrm{~m}$; staircase slab of $0.125 \mathrm{~m}$ thickness. The column sizes are of three types, " $0.23 \mathrm{~m} \times 0.45 \mathrm{~m}$ ", “ $0.23 \mathrm{~m} \times$ $0.60 \mathrm{~m}$ ", and " $0.30 \mathrm{~m} \times 0.90 \mathrm{~m}$ ". Floor beams size is “ $0.23 \mathrm{~m} \times 0.40 \mathrm{~m}$ ". Shear wall of thickness $0.2 \mathrm{~m}$ is provided in second building only.

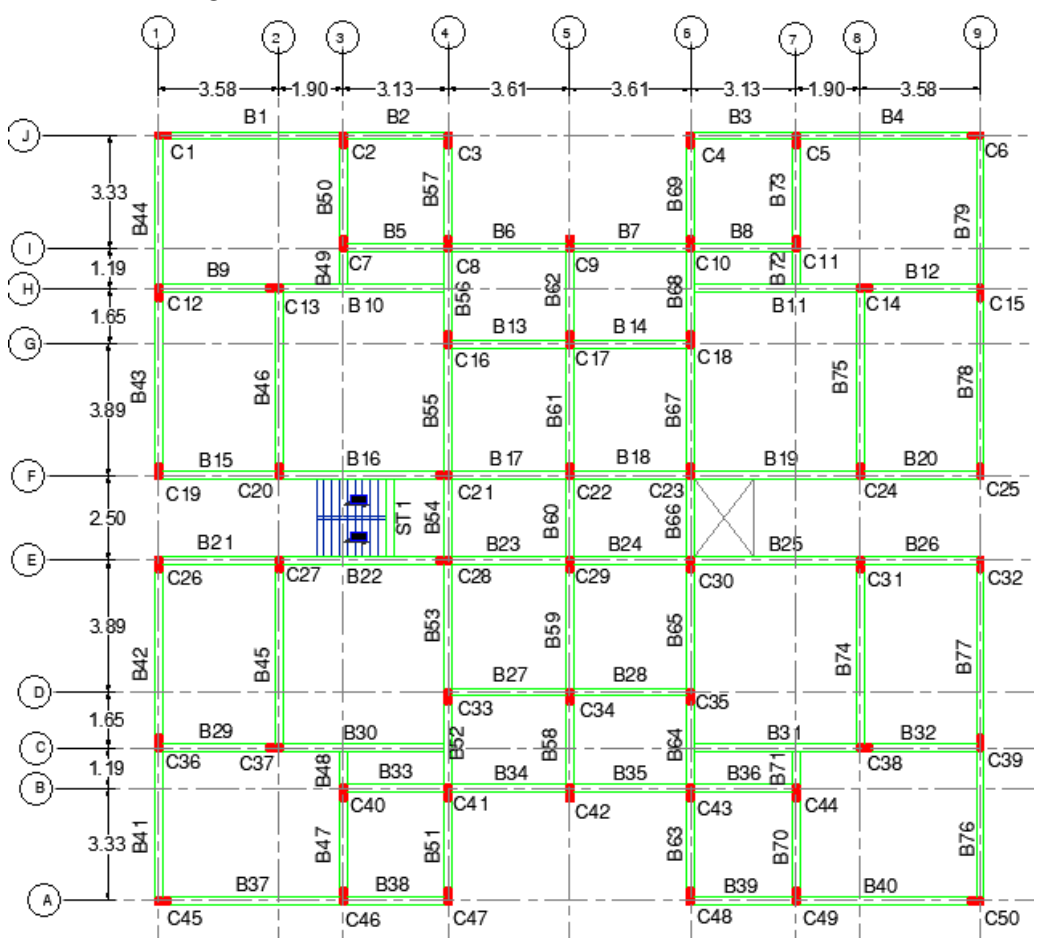

Fig. 4. Plan of Building

Table: 1 Concrete Property

\begin{tabular}{lc}
\hline $\begin{array}{l}\text { Concrete compressive strength } \\
\left(\mathrm{N} / \mathrm{mm}^{2}\right)\end{array}$ & 25 \\
Weight per unit volume $\left(\mathrm{kN} / \mathrm{m}^{3}\right)$ & 25 \\
Modulus of Elasticity $\left(\mathrm{N} / \mathrm{mm}^{2}\right)$ & 25000 \\
$\begin{array}{l}\text { Poisson's ratio } \\
\text { Coefficient of thermal expansion (per }\end{array}$ & 0.15 \\
degree Celsius) & 0.000008 \\
\hline
\end{tabular}

Table: 2 Steel Properties

\begin{tabular}{lc}
\hline Tensile strength $\left(\mathrm{N} / \mathrm{mm}^{2}\right)$ & 500 \\
Mass per unit volume $\left(\mathrm{kg} / \mathrm{m}^{3}\right)$ & 7849.05 \\
Modulus of Elasticity $\left(\mathrm{N} / \mathrm{mm}^{2}\right)$ & 200000 \\
Poisson's ratio & 0.28 \\
Coefficient of thermal expansion (per & 0.000009 \\
degree Celsius) & \\
\hline
\end{tabular}

Table: 3 Loading Assumptions

$\begin{array}{lc}\text { Dead Load }\left(\mathrm{kN} / \mathrm{m}^{2}\right) & 2 \\ \text { Load Load }\left(\mathrm{kN} / \mathrm{m}^{2}\right) & 2 \\ \text { External wall thickness }(\mathrm{mm}) & 230 \\ \text { Internal wall thickness }(\mathrm{mm}) & 150 \\ \text { Parapet wall }(1.5 \mathrm{~m} \text { height }) & 230 \\ \text { thickness }(\mathrm{mm}) & 50 \\ \text { Wind Load }(\mathrm{m} / \mathrm{s}) & \end{array}$

Table: 4 Seismic Data

\begin{tabular}{lccc}
\hline Parameters & Zone 3 & Zone 4 & Zone 5 \\
\hline $\begin{array}{l}\text { Total weight W } \\
(\mathrm{kN})\end{array}$ & 33420 & 33420 & 33420 \\
Zone Factor Z & 0.16 & 0.24 & 0.36 \\
Soil Type & 2 & 2 & 2 \\
Time Period T & 0.701 & 0.701 & 0.701 \\
Importance factor I & 1 & 1 & 1 \\
Response reduction & 5 & 5 & 5 \\
factor R & & & \\
Base shear V (kN) & 1037.4 & 1556.1 & 2334.1 \\
\hline
\end{tabular}


Available online at $w w w . i j r a t . o r g$

\section{RESULTS}

The calculations of the lateral loads, considered for the building structure is done with Indian Standard Code,
IS 1893 (Part 1):2002. The table 5 gives rundown of the outcomes of the lateral forces applied to every floor for every zone.

Table: 5 Results of the Lateral Forces

\begin{tabular}{|c|c|c|c|c|c|c|}
\hline \multirow{2}{*}{ Zone } & \multirow{2}{*}{ Level } & \multicolumn{2}{|c|}{ Without Shear Wall } & \multirow{2}{*}{ Hi (M) } & \multicolumn{2}{|c|}{ With Shear Wall } \\
\hline & & $\mathbf{V}(\mathbf{k N})$ & Fi $(\mathbf{k N})$ & & $\mathbf{V}(\mathbf{k N})$ & Fi $(\mathbf{k N})$ \\
\hline \multirow{5}{*}{ Zone 3} & Parking & \multirow{5}{*}{1037.4} & 0.46 & 2.5 & \multirow{5}{*}{1143.7} & 0.57 \\
\hline & Story 4 & & 39.04 & 14.5 & & 43.47 \\
\hline & Story 8 & & 130.4 & 26.5 & & 145.2 \\
\hline & Roof & & 217.6 & 35.5 & & 232 \\
\hline & Headroom & & 14.44 & 38.5 & & 14.59 \\
\hline \multirow{5}{*}{ Zone 4} & Parking & \multirow{5}{*}{1556.1} & 0.69 & 2.5 & \multirow{5}{*}{1715.7} & 0.86 \\
\hline & Story 4 & & 58.56 & 14.5 & & 65.21 \\
\hline & Story 8 & & 195.6 & 26.5 & & 217.8 \\
\hline & Roof & & 326.5 & 35.5 & & 348 \\
\hline & Headroom & & 21.66 & 38.5 & & 21.88 \\
\hline \multirow{5}{*}{ Zone 5} & Parking & \multirow{5}{*}{2334.1} & 1.04 & 2.5 & \multirow{5}{*}{2573.5} & 1.29 \\
\hline & Story 4 & & 87.84 & 14.5 & & 97.82 \\
\hline & Story 8 & & 293.4 & 26.5 & & 326.7 \\
\hline & Roof & & 489.7 & 35.5 & & 522 \\
\hline & Headroom & & 32.49 & 38.5 & & 32.82 \\
\hline
\end{tabular}

The following tables describe difference of the maximum top displacements for the zones considered for each structure, one is without shear wall and other is with shear wall.

Table: 6 Top Displacement of Structure (Without Shear Wall) For Each Zone

\begin{tabular}{ccc}
\hline $\begin{array}{c}\text { Displacement } \\
\text { Zone3 (m) }\end{array}$ & $\begin{array}{c}\text { Displacement } \\
\text { Zone4 (m) }\end{array}$ & $\begin{array}{c}\text { Displacement } \\
\text { Zone5 (m) }\end{array}$ \\
\hline 0.105 & 0.135 & 0.205 \\
\hline
\end{tabular}

Table: 7 Top Displacement of Structure (With Shear Wall) For Each Zone

\begin{tabular}{ccc}
\hline $\begin{array}{c}\text { Displacement } \\
\text { Zone3 (m) }\end{array}$ & $\begin{array}{c}\text { Displacement } \\
\text { Zone4 (m) }\end{array}$ & $\begin{array}{c}\text { Displacement } \\
\text { Zone5 (m) }\end{array}$ \\
\hline 0.06 & 0.075 & 0.111 \\
\hline
\end{tabular}

The non-linear static pushover analysis of the structure is performed using ETABS 2013, software that performs seismic analysis and design of buildings and structures. The hinges embedded in columns are defined to P-M2-M3 type; for beams the hinges are of type M3. The failure mode of the building structure under seismic excitations is plastics hinges formation. The fig. 5(a) and fig. 5(b) shows the plastics hinges formation for the lateral load and the deformed shape of both without and with shear wall structures for zone 3. 


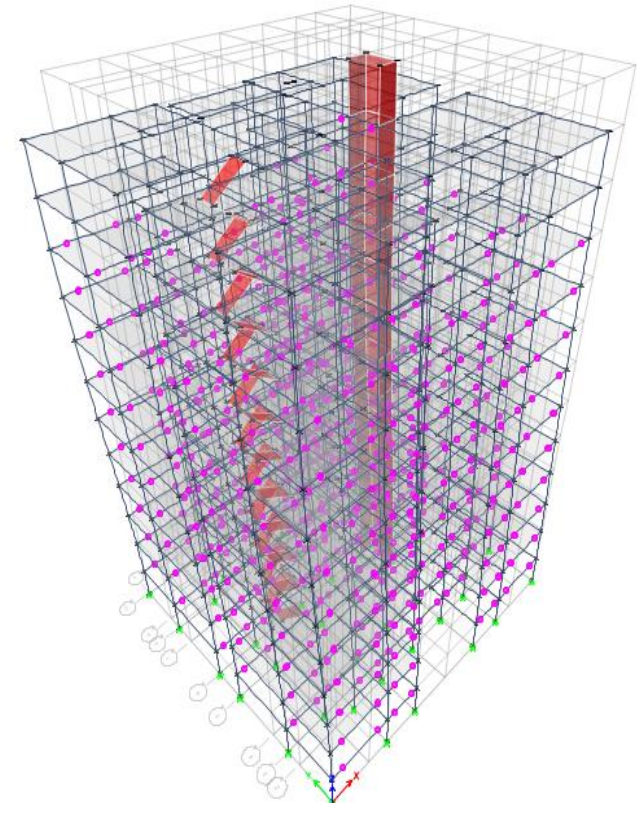

Fig. 5(a). Zone 3 Structure - Without Shear Walls

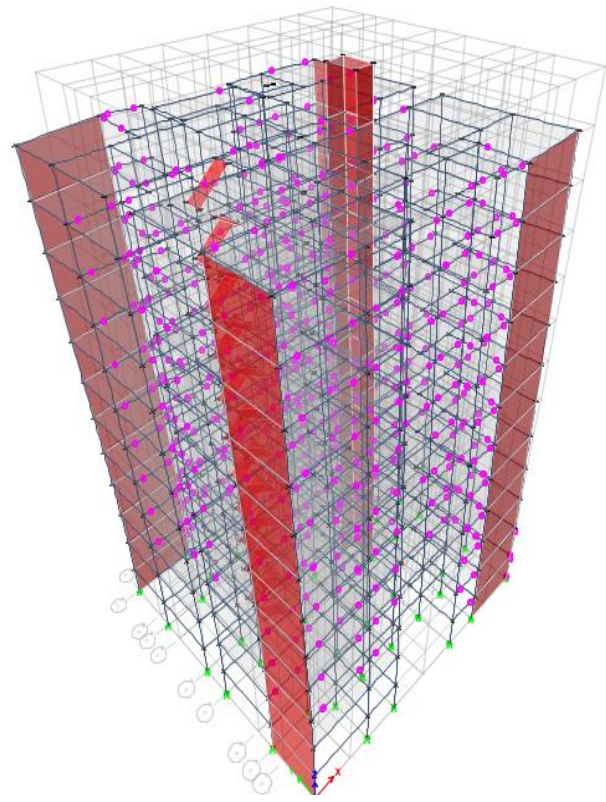

Fig. 5(b). Zone 3 Structure - With Shear Walls

The fig. 6 describes the pushover analysis curve i.e. a curve of displacement v/s base shear. Curves are given for both the type of structures in each zone.

\section{Displacementv/s Bace Shear}

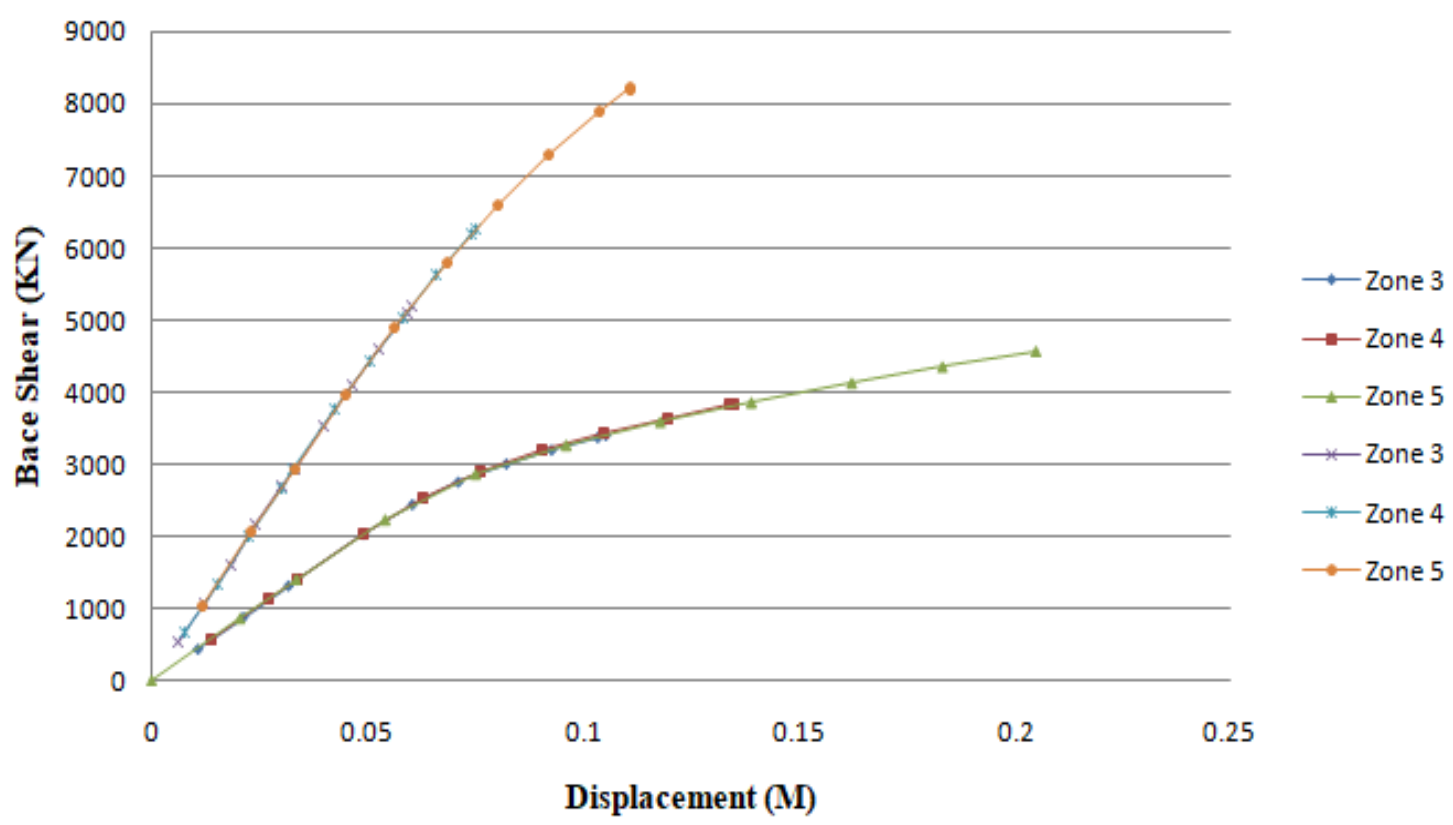

Fig. 6. Pushover Curve

The fig. 7 describes displacement difference in the seismic zones for without and with shear wall structures. 


\section{E-ISSN: 2321-9637 \\ Available online at www.ijrat.org}

\section{Difference in Displacements}

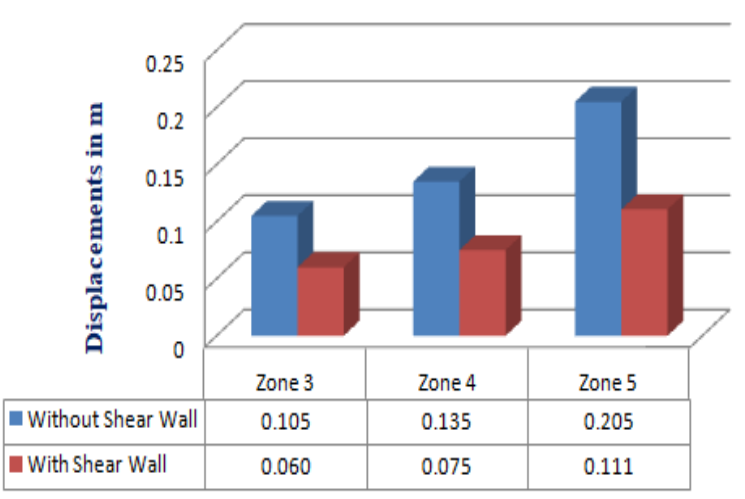

Fig. 7. Displacement Comparison

The fig. 8(a) and fig. 8(b) shows story drifts of all the floors of both the buildings in the three zones for without and with shear wall.

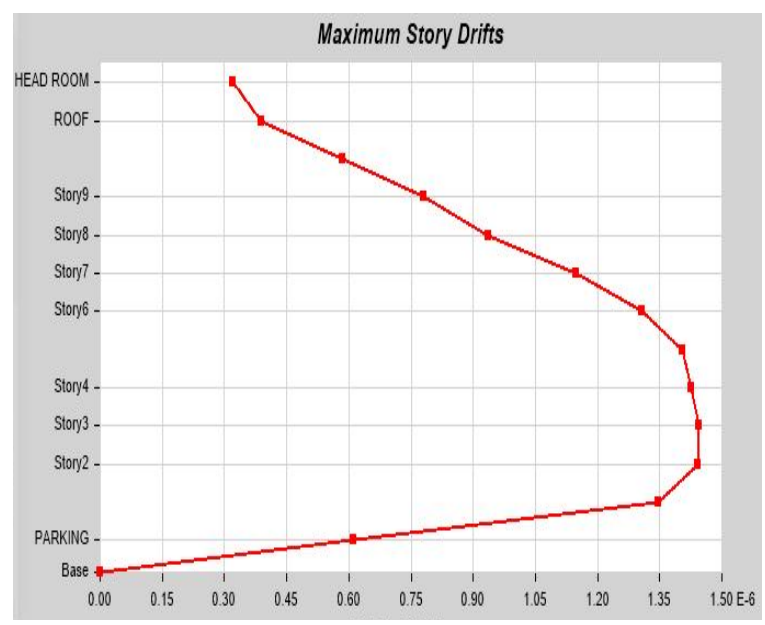

Fig. 8(a). Story Drift in 'mm' without Shear Wall (zone3)

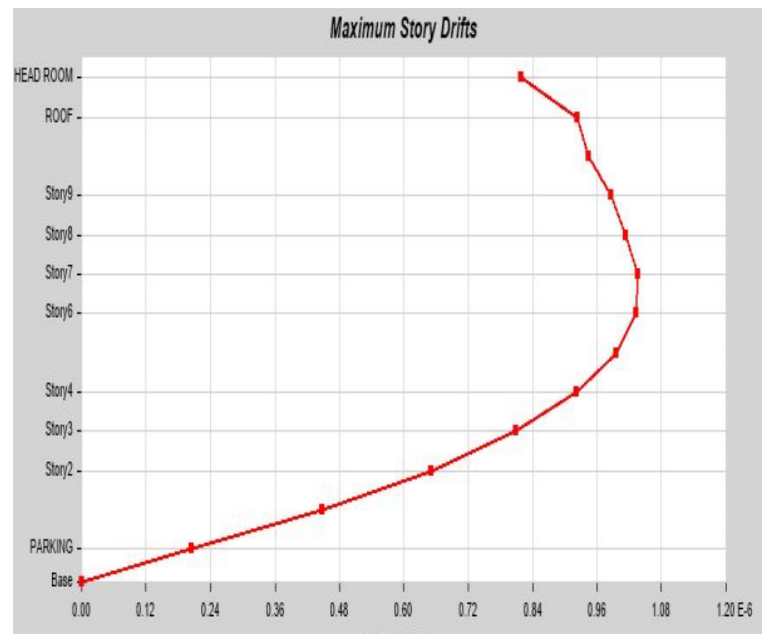

Fig. 8(b). Story Drift in 'mm' with Shear Wall (zone3)

\section{CONCLUSION}

The objective of this research was to study analytically and numerically the behavior of reinforced concrete building by non-linear static pushover analysis by comparison of without and with shear walls in building for zone 3, 4, and 5. Pushover curves (fig. 6) and tables (6 and 7) show variation in top displacements in the building models. It is seen that displacement increased from zone 3 to zone 5 . This is because of increase in lateral load in these respective zones with horizontal seismic coefficient and zone factor. Acceleration coefficient for zone 3 is 0.16 and for zone 5 is 0.36 . So, lateral force in zone 3 is 2.25 times higher than force in zone 5 seen in the table 4 . Comparing the displacement from table 6 and table 7 in all three zones, there is decrease of average $45 \%$ displacement when shear wall is considered. So, shear wall is a way of rehabilitation in buildings. Creation of pushover hinges shown in fig. 5(a) and 5(b) represents the cracking areas during pushover analysis, so that weak elements can be identified. Maximum story drift (fig. $8 \mathrm{a}$ ) is $1.43 \mathrm{~mm}$ at story 2 in zone 3 , in the building without shear walls. Whereas, maximum story drift (fig. 8b) is $1.03 \mathrm{~mm}$ at story 7 , in the building with shear walls. So, there is decrease in maximum story drift with application of shear walls in the structure.

The study has scope for future work. All this study is totally based on the analysis on the software. Experimental work can be done by preparation of actual model with shake table experiment. Time history analysis and response spectrum analysis can be done for this present model and comparison can be done with the pushover analysis. Other rehabilitation techniques can be provided to the present study such as base isolation system, dampers, bracings, etc.

\section{REFERENCES}

[1] ATC. (1996). "ATC 40: Seismic evaluation and retrofit of concrete buildings." Applied Technology Council, 1 and 2.

[2] Chopra, A. K., and Goel, R. K. (2004). "A modal pushover analysis procedure to estimate seismic demands for unsymmetric-plan buildings." Earthquake Engineering and Structural Dynamics, 33(8), 903-927.

[3] ETABS2000. Berkeley, CA: CSI: Computers and Structures Inc.; 2002.

[4] FEMA 273/274. NEHRP guidelines for the seismic rehabilitation of buildings. Federal Emergency Agency, 1997.

[5] FEMA (2000), Prestandard and Commentary for the Seismic Rehabilitation of Buildings, FEMA 356, Washington, DC: Federal Emergency Management Agency. 
International Journal of Research in Advent Technology, Vol.7, No.5, May 2019

E-ISSN: 2321-9637

Available online at www.ijrat.org

[6] Fajfar, P. (2000). "A Nonlinear Analysis Method for Performance-Based Seismic Design." Earthquake Spectra, 16(3), 573-592.

[7] Hasan, R., Xu, L., and Grierson, D. E. (2002). "Push-over analysis for performance-based seismic design." Computers and Structures, 80(31), 2483-2493.

[8] Jingjiang, S., Ono, T., Yangang, Z., and Wei, W. (2008). "Lateral load pattern in pushover analysis." Earthquake Engineering and Engineering Vibration, 2(1), 99-107.

[9] Kilar, V., and Fajfar, P. (1996). "Simplified pushover analysis of building structures." Eleventh World Conference on Earthquake Engineering.

[10] Kissi, B., Riyad, Y., Mrani, I., Parron, M. A., Labjar, N., Haouzi, A. El, El Fqih, M. A., and Guemimi, C. (2018). "Influence of zone type on performance of retrofitted Reinforced Concrete buildings by using Pushover Analysis." Materials Today: Proceedings, Elsevier Ltd, 5(1), 22-29.

[11]Le Nguyen, K., Brun, M., Limam, A., Ferrier, E., and Michel, L. (2014). "Pushover experiment and numerical analyses on CFRP-retrofit concrete shear walls with different aspect ratios." Composite Structures, Elsevier Ltd, 113(1), 403418.

[12] Providakis, C. P. (2008). "Pushover analysis of base-isolated steel-concrete composite structures under near-fault excitations." Soil Dynamics and Earthquake Engineering, 28(4), 293-304.

[13] Shakeri, K., Tarbali, K., and Mohebbi, M. (2014). "Pushover analysis of asymmetric-plan buildings based on distribution of the combined modal story shear and torsional moment." Earthquake Engineering and Engineering Vibration, 13(4), 707-716.

[14]IS: 1893. (2002). "“"Criteria for earthquake resistant design " fifth revision,Bureau of Indian Standard,New Delhi." 1893(June).

[15]Leslie, R. (2002). "The Pushover Analysis", explained in its Simplicity." 0,1-13. 